\title{
MASTERING THE SKILLS OF PROFESSIONAL CORRESPONDENCE IN MEDICAL ENGLISH FOR ACADEMIC PURPOSES
}

\section{ОПАНУВАННЯ НАВИЧОК ДІЛОВОГО ЛИСТУВАННЯ У ПРОЦЕСІ ВИКЛАДАННЯ ФАХОВОЇ АНГЛІЙСЬКОЇ МОВИ У МЕДИЧНИХ ВИШАХ}

\author{
Lysanets Yu.V. \\ orcid.org/0000-0003-0421-6362 \\ Candidate of Philological Sciences, Associate Professor, \\ Associate Professor of the Department of Foreign Languages with Latin \\ and medical terminology \\ Ukrainian Medical Stomatological Academy \\ Bieliaieva O.M., \\ orcid.org/0000-0001-9060-4753 \\ Candidate of Pedagogic Sciences, Associate Professor, \\ Head of the Department of Foreign Languages with Latin \\ and medical terminology \\ Ukrainian Medical Stomatological Academy
} Znamenska I.V.,
Candidate of Philological Sciences, Associate Professor,
orcid.org/0000-0001-7091-6215
Associate Professor of the Department of Foreign Languages with Latin
and medical terminology
Ukrainian Medical Stomatological Academy

Rozhenko I.V., orcid.org/0000-0001-6656-5117 Lecturer in the Department of Foreign Languages with Latin and medical terminology Ukrainian Medical Stomatological Academy

Nikolaieva N.M. orcid.org/0000-0003-1976-9517 Lecturer in the Department of Foreign Languages with Latin and medical terminology

Ukrainian Medical Stomatological Academy

The present article examines the mechanisms for improving the skills of professional correspondence while teaching the course in professional English for PhD students and academic staff at higher medical educational institutions. The authors developed their own concept of presenting the training material. The proposed approach has been tested in the development of the textbook "Medical English for Academic Purposes" (2018), which was written in the context of current trends in internationalised higher education, involving the training of specialists who will work in the modern English language educational and scientific environment. Each unit presents grammar and uses exercises and illustrative material to consolidate and activate the professional oral and written use of vocabulary and specialised terminology. The exercises approximate to tasks used in Cambridge English and IELTS International examinations (Writing and Speaking Modules). Extracts from original professional literature demonstrate the use of medical terminology. Theoretical aspects are introduced within the most common syntactic constructions in modern spoken and written scientific discourse. The authors suggested a classification of modern professional correspondence, the most common phrases, used for writing letters and e-mails, as well as a cycle of training tasks, aimed at revising the grammar material, control of the level of mastering the lexis, creating didactic conditions for developing business correspondence skills, writing case histories, discharge summaries and other genres of English medical discourse, as well as preparing for international ESOL exams. The research will be useful for translation studies, teaching English as a second language, and developing multilingual competence of future doctors.

Key words: English for Professional Purposes, academic staff, PhD students.

У статті досліджено механізми поліпшення навичок ділового листування у процесі викладання курсу фахової англійської мови для науково-педагогічних працівників та здобувачів ступеня доктора фрілософії. Розроблено цикл навчальних вправ, спрямований на вдосконалення навичок професійної комунікації у процесі викладання фахової англійської мови у медичних вишах. Представлено класифікацію сучасної ділової кореспонденції, найуживаніші фрази-кліше для написання листів та електронних повідомлень, закріплення граматичного матеріалу, контролю 
засвоєння лексики, створення дидактичних умов для формування навичок ділового листування, написання історії хвороби, виписного епікризу та інших жанрів англомовного медичного дискурсу, а також підготовку до міжнародних іспитів Cambridge English та IELTS. Пропонований підхід спрямований на розвиток комунікативних навичок, необхідних для успішного міжнародного спілкування і співпраці, та апробований під час розробки підручника "Меdical English for Academic Purposes" (2018), який укладено з урахуванням сучасних тенденцій інтернаціоналізації вищої школи, що передбачає підготовку фрахівців, які працюватимуть в англомовному просторі сучасної науки й освіти. Авторами вироблена власна концепція викладу навчального матеріалу. У підручнику запропоновано фрагменти текстів з оригінальних джерел сучасної англомовної фахової літератури за тематичним принципом, що полегшує опрацювання галузевої термінології. Тексти супроводжуються розлогою мережею завдань, які закріплюють розмаїтий матеріал: граматику, загальновживану та загальнонаукову лексику, вузькофахові термінології. Представлено досвід упровадження комплексного підходу у процесі викладання курсу фрахової англійської мови для науковопедагогічних працівників та здобувачів ступеня доктора фрілософії у медичних вишах.

Ключові слова: фахова англійська мова, науково-педагогічні працівники, здобувачі ступеня доктора фрілософії.

The skills of professional correspondence (in particular, writing business letters and e-mails) constitute a strategic prerequisite for the advancement of higher medical education in Ukraine [8]. The major challenges in academic English vocabulary in terms of spelling and punctuation have already been discussed in our previous studies $[1 ; 2 ; 4 ; 5$; $6 ; 7]$. The present paper focuses on the methods of developing professional correspondence skills of Ph.D. students, academic and clinical teachers of English-speaking medical students. The results of the research have been integrated into the 1st edition of Medical English for Academic Purposes by Yu. Lysanets, O. Bieliaieva, M. Melaschenko (2018) [3], which focuses on improving the communication skills of medical professionals in a foreign-language professional setting. The skills in writing effective business letters and e-mails are essential for successful international communication and cooperation, which renders the present research relevant.

The text of a business letter must be concise, consistent, convincing and gramatically correct. The facts and events should be expressed objectively, all aspects of the considered issues should be explained in a clear, but a sufficiently complete, manner. Business letters and e-mails are usually sent to encourage the addressee to act, to explain something, to convince him/her of something. This can be achieved due to the precision of the text and the content of the letter. In order to consolidate the most common phrases, used in business letters and e-mails, we developed the guidelines, presented in Table 1.

Table 1

Vocabulary for Professional Letters and E-Mails Initial Greeting (salutation)

Dear John/Jane [informal and if you know the person well]

Dear Professor / Dr./Mr./Mrs/Miss Brown [standard/formal]

Dear Ms Smith [if you don't know which title a woman prefers]

Dear Sir or Madam [If you do not know the point of contact in an organisation]

To whom it may concern [specific point of contact unknown]

Introductory phrases and referring to previous contact

I/We are writing to inform you that/to confirm/to request/ Thank you for your letter of March 15.

to enquire about...

I am contacting you about...

I recently $\mathrm{read} /$ heard about...

I would like to know if it is possible to...

Having read your research paper in..., I would like to...

I would be interested in (obtaining/receiving)...

Thank you for contacting us.

In reply to your request, ...

Thank you for your letter regarding...

Reference to our telephone conversation yesterday...

Further to our meeting last week...

It was a pleasure meeting you at...

I would like to confirm the main points we discussed on Tuesday.

\section{Requests and Offers}

We would appreciate it if you could...

I would be grateful if you could...

Could you please send me...

Could you possibly tell us/let us...

I would also like to receive...

It would be helpful if you could send

Would you like us to send/do etc...?

\section{News}

We are pleased to announce that...

I am delighted to inform you that...

I am very happy to say that...

We would be happy to send/review etc...

We are quite willing to...

Our company would be pleased to...

We are highly interested in... Please let me know what actions you propose to take.

I would appreciate your immediate attention to this matter.

We regret that we are unable to...

Unfortunately, it will not be possible to...

After careful consideration, we have decided... 


\section{Complaining}

I am writing to express my dissatisfaction with...

I am writing to complain about...

Please note that our request remains open.

\section{Final statements}

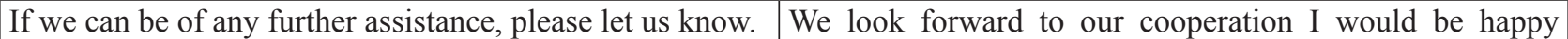
If I can help in any way, please do not hesitate to contact to work with you further... me.

If you require more information...

For further details...

Thank you for taking this into consideration.

Thank you for your help.

Thank you for your time and attention.

We are sorry for the delay in replying to...

I regret any inconvenience caused (by)...

I would like to apologise for the (delay, inconvenience)... Please accept my apologies for.

Enclosures \& Attachments, Signing off

I am enclosing...

Please find attached...

Enclosed are the following documents:

Yours Sincerely [standard ] [note: "yours faithfully" is now rarely used]

Kind regards/Best regards/Regards

Within the structure of professional correspondence, one can define a range of specific genres. Information letters are used to inform the addressee of any facts or events. As a rule, the addresser offers their products or services. The information contained in letters of this type should be as wide as possible. Promotional letters contain a detailed description of goods or services and are sent to specific recipients in order to encourage them to take advantage of the ones offered. Letters of invitation are used to suggest a specific person or an institution to take part in some kind of events. Cover letters are sent to inform the addressee about the sending of documents attached to the letter. Letters of approval are official letters confirming a certain fact, for example, the receipt of money transfers, etc. Letters of reminder are used to remind us of the approaching or expiration of certain tasks (commitments). Letters of recommendation are issued at the request for a position, application for a grant, etc.

The sample tasks given below are intended to reinforce and activate the professional correspondence skills.

Sample tasks:

\section{Ex. 1. Read the letters between medical professionals from Occupational English Test (OET). Pay attention to the correspondence structure and style: \\ Letter 1}

\section{March 2016}

Re: Ms Anne Hall, DOB 19.9.1965

Dear Dr Roberts,

Thank you for seeing Ms Hall, a 44-year-old secondary school teacher, who is presenting with a two-week history of symptoms of dysphagia for solids, epigastric pain radiating posteriorly to T12 level, and concomitant weight loss. The symptoms follow a constant course. Ms Hall believes the problem commenced after an upper respiratory tract infection two weeks ago for which she self-prescribed an over-the-counter Chinese herbal product with unknown ingredients. However, she has also recently increased her coffee consumption and takes aspirin 2-3 times a month. She has a history of dyspepsia (2004), and dermatitis for which she was prescribed oral and topical cortisone. There are no apparent signs of anxiety. She has not smoked for the last 15 years. She drinks socially (mainly spirits), has a family history of peptic ulcer disease and is allergic to codeine. Her BMI is currently 28.2.

My provisional diagnosis at this point is gastro-oesophageal reflux with possible stricture. I am therefore referring Ms Hall to you for further investigation.

Thank you for assessment and ongoing management of this woman. If you require any further information, please do not hesitate to contact me.

Yours sincerely

Doctor

\section{Letter 2}

10 February 2014

Re: Mrs Priya Sharma, 71 Seaside Street, Newtown, DOB 08.05.53

Dear Dr Smith,

Thank you for seeing Mrs Priya Sharma, a type 2 diabetic. I would be grateful if you would assist with her blood sugar control. Mrs Sharma is 60 years old and has a strong family history of diabetes. She was diagnosed with NIDDM in 1994 and has been successfully monitoring her BP and sugar levels at home since then. She first attended my surgery 
on 29/12/13 as she was concerned that her blood sugar levels were no longer well controlled. On initial presentation her BP was 155/100 and she said that her blood sugars were running between 6 and 18. Her medication at that time was metformin 500mg x2 nocte and glipizide 5mg x2 mane. Mrs Sharma is allergic to penicillin. A pathology report on 05/01/2014 showed HbAlc levels of $10 \%$ and GFR greater than $60 \mathrm{ml} / \mathrm{min}$. Her cholesterol was high (6.2). On 29/12/13, I instituted Atacand 4mg, 1 tablet each morning. Since then her home-monitored BP has been within range. On 12/01/14, I also prescribed Lipitor 20mg daily, and her lipids have improved, with cholesterol falling from 6.2 to 3.2 . Mrs Sharma reports that her fasting BSL is in the 16+ range (other blood sugars are 7-8). I am concerned about her fasting blood sugars, which remain high, and would appreciate your advice.

Yours sincerely,

Doctor

Source: www.occupationalenglishtest.org/resources/uploads/2015/07/Writing-Medicine-Sample-Test-1-2010.pdf)

The didactic purposes of the tasks: a) to revise the relevant lexis; b) to practice different verb tenses and voices; c) to master the skills of coherence and cohesion in producing the English professional correspondence.

Ex. 2. Read the discharge summary given below:

\section{DEPARTMENT OF GYNAECOLOGY}

Patient Name: Jane Smith

Age:29 Years Sex: Female DOA: 24/06/15 15:48

DIAGNOSIS: Primigravida with 17 weeks of pregnancy with inevitable abortion. Blood Group: A+Ve

PRESENTING COMPLAINTS: Patient admitted with complaints of something coming out of vagina for 2 hours and pain lower abdomen. LMP- 25/02/2015; EDD- 01/12/2015; O/H- G1 P0 L0

PAST HISTORY: -Nil significant. FAMILY HISTORY: -Nil significant. GENERAL PHYSICAL EXAMINATION: Conscious, alert well oriented Chest-Bilateral clear. CVS-NAB; Breast-NAD. Pulse $-80 / \mathrm{mm}, \mathrm{BP}-110 / 70 \mathrm{mmHg}$ SYSTEMIC / LOCAL EXAMINATION: PA- Uterus 16 weeks size, FHS not present. P/V-OS 6-7 cm, partially efface, bag felt in canal. HOSPITAL COURSE: Under all aseptic precaution patient expelled foetus at 8:40 A.M. on 25/06/2015. Specimen sent for chromosomal analysis (karyotyping). Tab. Cabgolin given.

CONDITION AT DISCHARGE: Satisfactory

Ex. 3. Using the information from the Discharge Summary in Ex. 2, write a letter of patient's referral for next appointment at Gynaecology OPD to Dr. Leslie Winkle. Expand the relevant notes into complete sentences. Use letter format (approximately 180-200 words).

The didactic purposes of the task: a) to revise the Latin terminology and medical abbreviations in the genre of discharge summary; b) to use adequately different verb tenses and voices; c) to develop the skills of coherence and cohesion in producing the English professional correspondence; d) to master the skill of writing a referral letter.

In order to revise the structure and style of discharge summary and other medical documents, which may be used in professional correspondence, we developed the following exercise:

Ex. 4. The diagram shows types of medical documents.

State which: a) is written when a patient checks out of the hospital; b) provides the details of the medical checkup; c) details the procedures and findings of a surgical operation; d) provides the details of the psychiatric examination; e) gives the patient's personal data and condition when they enter a hospital; f) gives the post mortem/autopsy findings on the cause and manner of death; g) is a written statement from a physician about a patient's health; h) is a legal document signed by patients before treatment or operation; i) presents analysis of experiments, specimens, pathology report; j) summarises immunizations given and those still pending; $\mathrm{k}$ ) is a patient's report after specific questions, to help with diagnosis and treatment; 1) gives evidence that a person is unfit for work.

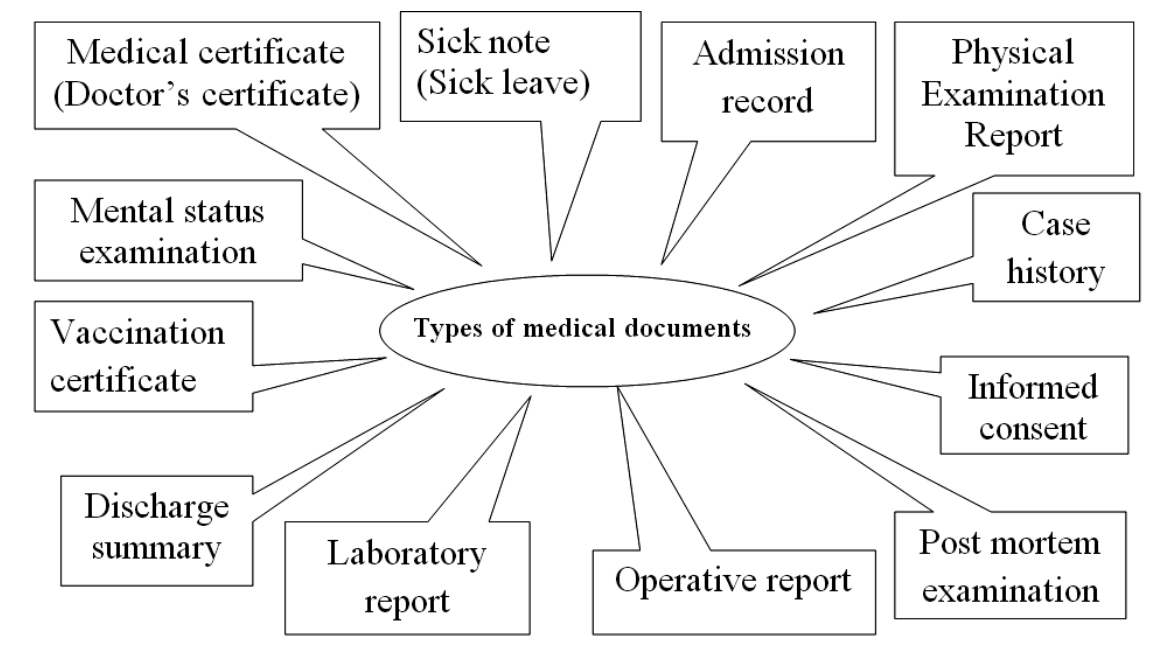


Ex. 5. Read the sample cover letter given below. Pay attention to its structure and style.

To the Editor

Sub: Submission of Manuscript for publication Dear Sir,

We intend to publish an article entitled “ "(authors:

) in your esteemed journal as an Original Article.

On behalf of all the contributors I will act and guarantor and will correspond with the journal from this point onward. This manuscript describes original work and is not under consideration by any other journal. The research has not been submitted to prior publications or presentations in a conference/seminar. The authors have no support in financial or other manner to report. The authors have no conflict of interest to declare. No permissions for reproducing pre-published information/material are needed. We hereby transfer, assign, or otherwise convey all copyright ownership, including any and all rights incidental thereto, exclusively to the journal, in the event that such work is published by the journal.
Thank you for receiving my manuscript and considering it for review.

Yours sincerely,

The didactic purposes of the task: a) to learn and revise the structure and style of cover letters; b) to use adequately different verb tenses and voices; c) to develop the skills of coherence and cohesion in producing the English professional correspondence; d) to master the skills of writing a cover letters.

Thus, rapid development of integration in Ukraine requires to place a more focused emphasis on international communication by means of business letter and e-mails, which will enable the Ukrainian medical PhD students and staff to produce the English-language professional discourse of a competitive quality and thus to succeed at the international arena. Therefore, one of the most relevant tasks of teaching English for Academic Purposes is developing the grammar and vocabulary competence with a view to improve the professional correspondence skills.

\section{REFERENCES:}

1. Бєляєва О.М. Функціонально-змістовні та функціонально-стильові характеристики наукових текстів. Інновації в освіті, науці та виробництві : матеріали шостої Всеукр. конф. (Полтава, $23-24$ квіт. 2009 р.). Полтава, 2009. С. 108-110.

2. Bieliaieva O.M., Lysanets Yu.V., Znamenska I.V., Rozhenko I.V., Nikolaieva N.M. Terminological collocations in medical Latin and English: A comparative study. Wiadomości Lekarskie. 2017. No 70 (1). Pp. 139-143.

3. Lysanets Yu., Bieliaieva O., Melaschenko M. Medical English for Academic Purposes. Kyiv : AUS Medicine Publishing, 2018. 312 p.

4. Bieliaieva O., Lysanets Yu., Havrylieva K., Znamenska I., Rozhenko I., Nikolaieva N. Paronymy in the Sublanguage of Medicine (Linguistic and Linguo-Didactic Aspects). Georgian Medical News. 2017. No. 10 (271). P. 144-149.

5. Bieliaieva O., Synytsia V., Lysanets Yu. Pharmaceutical Terms with Onomastic Component: Quantitative, Structural and Lexico-Semantic Analysis. Wiadomości Lekarskie. 2018. Vol. 71. Nr. 1. cz. II. P. $217-221$.

6. Lysanets Yu., Bieliaieva O., Nikolaieva N. Pseudo-Internationalisms in the Language of Medicine and Healthcare as a Challenge for Translation Studies. Актуальні проблеми романо-германської фрілології та прикладної лінгвістики: науковий журнал. Чернівці, 2017. Вип. 2 (15). С. 46-49.

7. Lysanets Yu., Bieliaieva O. The use of Latin terminology in medical case reports: Quantitative, structural, and thematic analysis. Journal of Medical Case Reports. 2018. 12:45. URL: https://jmedicalcasereports.biomedcentral. com/articles/10.1186/s13256-018-1562-x.

8. Morokhovets H., Lysanets Yu. Developing the professional competence of future doctors in the instructional setting of higher medical educational institutions. Wiadomości Lekarskie. 2017. No 70 (1). Pp. 101-104. 